\title{
Új generációs szekvenálás és használata az aneuploidiák nem invazív praenatalis vizsgálatában
}

\author{
Babay Lilla Éva oh. ${ }^{1}$ - Horányi Dániel dr. ${ }^{2}$ - Rigó János Jr. dr. ${ }^{1}$ \\ Nagy Gyula Richárd dr. ${ }^{1}$ \\ ${ }^{1}$ Semmelweis Egyetem, Általános Orvostudományi Kar, I. Szülészeti és Nőgyógyászati Klinika, Budapest \\ ${ }^{2}$ Egyesített Szent István és Szent László Kórház, Szülészeti és Nőgyógyászati Osztály, Budapest
}

\begin{abstract}
Az új generációs szekvenálási eljárások fejlődésével a génszekvenálás új korszaka köszöntött be, amely a noninvazív aneuploidiavizsgálatokat is forradalmasította. Összefoglaló közleményükben a szerzők a teljesebb kép érdekében bizonyos első generációs szekvenálási módszerek leírása után lépésról lépésre ismertetik az egyes új generációs eljárások eltérő elméleti és technikai hátterét. Közleményük második felében a fejlett szekvenálási eljárásokat igénylő, magzati szabad DNS segítségével történő noninvazív praenatalis tesztelésre helyezik a hangsúlyt: a vizsgálat elméleti alapjainak és konkrét technikai kivitelezésének összefoglalása után ismertetik a vizsgálat jelenlegi szerepét és használhatóságát az aneuploidiadiagnosztikában. Megállapítják, hogy a noninvazív praenatalis tesztelés a jelenleg leghatékonyabb aneuploidiaszürő módszer magas kockázatú terhesek esetén, hatékonysága pedig alacsony kockázatú terhességek esetén is tanulmányokkal igazolható. Orv. Hetil., 2015, 156(26), 1041-1048.
\end{abstract}

Kulcsszavak: új generációs szekvenálás, szabad DNS, noninvazív praenatalis tesztelés

\section{Next generation sequencing and its applications in non-invasive prenatal testing of aneuploidies}

The development of the new generation sequencing techniques brought a new era in the field of DNA sequencing, that also revolutionized the prenatal screening for aneuploidy. In order to provide a more complete view, the authors describe some first generation methods as well as the theoretical and technical background of the next generation methods. In the second part of this review, the authors focuse on non-invasive prenatal testing, which is a fetal cellfree DNA based method requiring advanced sequencing procedures. After discussing the theoretical and technical background, the authors review current application and utility of non-invasive prenatal testing. They conclude that non-invasive prenatal testing is the most effective screening test in high risk pregnancies and its efficiency can be justified in studies involving low risk pregnancies as well.

Keywords: next generation sequencing, cell-free DNA, non-invasive prenatal testing

Babay, L. É., Horányi, D., Rigó, J. Jr., Nagy, Gy. R. [Next generation sequencing and its applications in non-invasive prenatal testing of aneuploidies]. Orv. Hetil., 2015, 156(26), 1041-1048.

(Beérkezett: 2015. április 23.; elfogadva: 2015. május 14.)

\section{Rövidítések}

$\mathrm{A}=$ adenin; $\mathrm{ATP}=$ adenozin-trifoszfát; $\mathrm{C}=$ citozin; $\mathrm{CRT}=($ cyclic reversible termination $)$ ciklikus reverzíbilis termináció; ddNTP = didezoxinukleotid-trifoszfát; DNS = dezoxiribonukleinsav; $\mathrm{dNTP}=$ dezoxinukleotid-trifoszfát; $\mathrm{FF}=$ magzati frakció; $\mathrm{G}=$ guanin; $\mathrm{GE}$ = genomegység;
MPS = (massively parallel sequencing) masszív párhuzamos szekvenálás; $\mathrm{NCV}=$ (normalized chromosome value) normalizált kromoszomális érték; NGS = (next generation sequencing) új generációs szekvenálás; NIPT = nem invazív praenatalis tesztelés; $\mathrm{PCR}=($ polymerase chain reaction $)$ polimeráz láncreakció; $\mathrm{s}-\mathrm{MPS}=($ shotgun massively parallel sequencing $)$ teljes 
genomot érintő masszív párhuzamos szekvenálás; SNP = (single nucleotide polymorphism) egy nukleotidot érintő génpolimorfizmus; $\mathrm{T}=$ timin; $\mathrm{t}$-MPS $=$ (targeted massively parallel sequencing) célzott masszív párhuzamos szekvenálás; TCEP $=\operatorname{tris}(2$-carboxyethyl $)$ phosphine

A perinatalis veszteségek és a veleszületett súlyos mentális retardációk hátterében igen gyakran állnak kromoszóma-rendellenességek. Születéskori gyakoriságuk 1:180, és ezek körülbelül kétharmadát az aneuploidiák és a polyploidiák teszik ki. Tekintettel arra, hogy az aneuploidiák primer prevenciójára jelenleg nincs mód, ezért a megelőzésre csak a szekunder prevenció, vagyis a terhességmegszakítás módszerét alkalmazhatjuk. Ezen okok miatt a kromoszómaeltérések minél hamarabbi felismerése a legtöbb társadalomban jelentős igény, s ebben lehetnek segítségünkre a szürő és diagnosztikus célból végzett praenatalis vizsgálatok [1].

Noninvazív beavatkozások esetén arra törekszünk, hogy a születendő magzat veszélyeztetése nélkül nyerjünk információt annak fejlődéséről, életkilátásairól és az ezeket meghatározó genetikai állományáról. Ilyen módszernek számít a magzati ultrahangvizsgálat, az anyai szérum vizsgálata, a két módszer kombinációja, valamint a magzati sejtek és szabad magzati DNS anyai vérből történő vizsgálata (noninvazív praenatalis tesztelés - NIPT) is. Az NIPT a noninvazív vizsgálómódszerek új generációját jelenti, hiszen a szürőmódszerek közül a legmagasabb szenzitivitással rendelkezik, hatékonyságának alapját pedig a gyors, pontos és pillanatnyilag még drága, de már megfizethető új generációs génszekvenálási módszerek adják.

A génszekvenálás a DNS-lánc nukleotidsav-sorrendjének meghatározását jelenti [2]. Az első jelentős szekvenálási módszer Sanger [3] nevéhez füződik, aki 1977 ben írta le később rendkívüli népszerüségnek örvendő didezoxinukleotid (ddNTP) láncterminációs módszerét. A metódus lényege, hogy a növekvő DNS-szálba beépülő ddNTP megakadályozza a DNS-polimeráz által történő további lánchosszabbítást, ennek oka, hogy nem rendelkezik 3'-hidroxil-véggel, így nem jöhet létre a következő nukleotid beépülését lehetővé tevő foszfodiészterkötés. A rendszerbe feleslegben tesznek szabályos dezoxiribonukleotidokat, mert különben egyáltalán nem szintetizálódna DNS. A szintézist négy kémcsőben végzik. Mindegyikhez különböző didezoxinukleotidokat adnak, így a lánctermináció a négy közül mindig az adott típusnál áll le. A reakció eredményeként mindegyik kémcsőben különböző hosszúságú fragmentumok sorozata képződik, s egy adott kémcsóben mindegyik fragmentum ugyanarra a nukleotidra végződik. A négy mintát egymás mellett futtatják egyazon gélben, amelynek során a különböző hosszúságú fragmentumok méretük függvényében szétválnak, s így lehetővé teszik a nukleotidok sorrendjének meghatározását. A Sanger által kidolgozott eljárás hátránya, hogy egy leolvasásban olvasható bázisok száma korlátozott (500-600), ezt követően a lapos görbék miatt bizonytalanná válik a leolvasás. Az eljárás során olyan nagy mennyiségú templátot és primert nem tudnak bevinni, hogy csak például a 600.-nál épüljön be a didezoxibázis.

A kezdetekben a DNS-fragmentumok szeparálására a poliakrilamid gél elektroforézist, míg detekciójára a radioaktivitással vagy fluoreszcenciával jelölt dezoxinukleotidokat (dNTP) használták, ezeket később fluoreszcenciával jelölt didezoxinukleotidokra [4] (ddNTP) és kapilláris gélelektroforézisre [5] cserélték, ezzel a vizsgálat érzékenységének növekedését érték el a költségek csökkentése mellett [6].

A génszekvenálás első valós idejü detekciót lehetővé tevő módszere az 1996-ban Ronaghi és mtsai [7] által publikált piroszekvenálási eljárás volt. Ez a módszer a beépült bázist nem a DNS-ben levő jel alapján, hanem a nukleotidok beépülése során felszabaduló pirofoszfát átalakításán keresztül detektálja, amely három enzim (ATP-szulfuráz, luciferáz, apiráz) részvételével végbemenő kemifluoreszcens reakció útján válik lehetővé. Amikor egy nukleotid beépül a DNS-szálba, pirofoszfát keletkezik, és ennek a mennyiségét mérjük egy kapcsolt reakcióval, amit végül a luciferáz enzim felvillanással jelez. Egyszerre csak egyféle nukleotidot adnak a rendszerhez, így biztos, hogy csak egy nukleotid fog beépülni a növekvő szálba. Ha több nukleotid épül be, arra a fényintenzitás növekedéséből lehet következtetni. A módszer diagnosztikus korlátai (a Sanger-féle módszerhez hasonlóan a hosszabb láncok szekvenálási képtelensége) miatt széles körben sosem terjedt el, viszont a piroszekvenálási technika és a valós idejű szekvenálás ideológiája megfelelő alapot szolgáltatott az új generációs szekvenálási eljárások kifejlődésének.

Új generációs szekvenálási eljárásoknak (next generation sequencing - NGS, massively parallel sequencing MPS) nevezzük azokat, amelyek a Sanger-féle láncterminációs módszer és a kezdeti piroszekvenálási eljárás (első generációs szekvenálási módszerek) után kerültek kifejlesztésre [6]. A módszerek a technikai kivitelezésben eltérnek egymástól, közös tulajdonságuk viszont, hogy a masszív, párhuzamosan zajló szekvenálási reakciók eredményeképpen rendkívül nagy mennyiségú adatot képesek előállítani, az első generációs szekvenálási módszerekhez viszonyítva jelentősen alacsonyabb áron [8].

Összefoglaló közleményünkben az új generációs szekvenálási eljárások alapjainak bemutatása után azok noninvazív praenatalis aneuploidiavizsgálatokban betöltött szerepére fokuszálunk.

\section{Az új generációs szekvenálási eljárások technikai alapjai}

Az új generációs szekvenálás $[6,8]$ lényege leegyszerúsítve, hogy az előzetesen elókészített DNS-szakaszokat szeparált klonális amplifikációt követően parallel szekvenáljuk, így hatalmas mennyiségú adathoz juthatunk, 


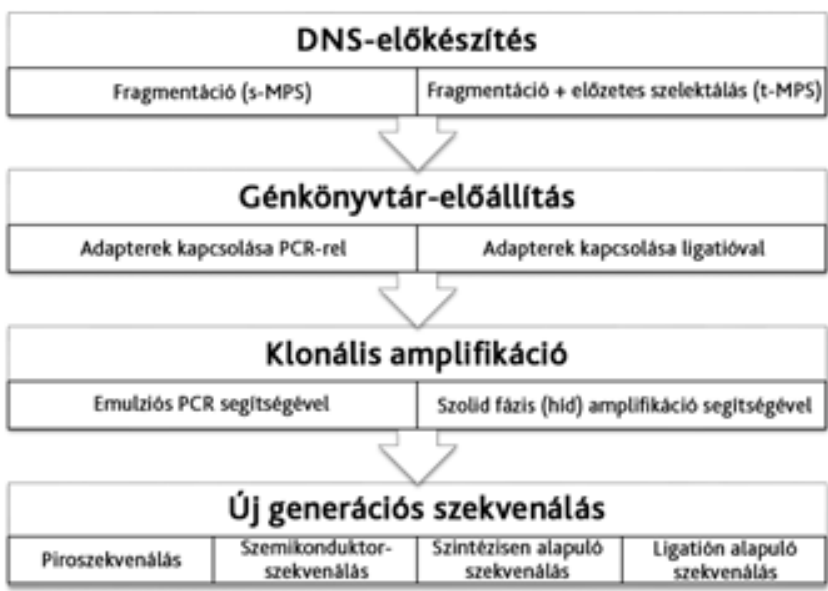

1. ábra

| Az új generációs szekvenálási eljárások főbb lépései

amelyeket analizálva a DNS nukleotidsav-sorrendjéről relatíve rövid idő alatt nyerhetünk releváns információt.

$\mathrm{Az}$ új generációs szekvenálás több eltérő módszert foglal magába, amelyek a minta-elókészítés, a génkönyvtár-előállítás, klonális amplifikáció, szekvenálás és adatanalízis lépéseiben (1. ábra) alkalmaznak különféle eljárásokat.

\section{Minta-előkészités}

Az NGS-reakciók első lépésében a DNS elókészítésre kell kerüljön. Az első kérdés már ilyenkor felmerül: Vannak olyan célzott szekvenciák, esetleg kromoszómák, amelyek érdeklődésünk kizárólagos középpontjában állnak? Ugyanis a vizsgálat fókusza alapján a masszív parallel szekvenálási reakciókat két nagy csoportra oszthatjuk, ezek a célzott (targeted, t-MPS) és az egész genomot átfogó (shotgun, s-MPS) szekvenálási reakciók. A teljesgenom-szélességre kiterjedő szekvenálás során az elérhető DNS-szakaszok mindegyikét szekvenáljuk, míg célzott szekvenáláskor egy előzetes szelektálási lépés után csak az általunk érdekesnek vélt génszakasz vizsgálatát végezzük el [9].

Mindkét módszer esetén az előkészítés kezdeti lépése a DNS-fragmentáció, amelynek során a DNS-t 50-500 bázispár nagyságú darabokra tördelik mechanikai erő, enzimatikus emésztés vagy transzpozonok random beszúrása segítségével $[10,11]$.

A DNS kiindulási mennyisége hatással van a fragmentációra, és ezáltal a későbbi szekvenálási folyamatra is, mivel alacsony mennyiségú DNS esetén rövidebb bázishosszú töredékek készülhetnek, míg nagyobb mennyiségú DNS esetén hosszabb fragmentumok jöhetnek létre, amelyek meghatározzák a szekvenálási módszereket (fragmentált és mindkét végükön szekvenálható templátok [8]).
Mivel a shotgun szekvenálás során nincs szükségünk elózetes szelekcióra, ezért az elókészítés a fragmentációval be is fejezódik.

Ettől eltérően, célzott szekvenálás során szükség van egy ezt követő szelektálási lépésre, amelynek célja kiválasztani az általunk vizsgálni kívánt génszakaszokat. Ez megvalósulhat különféle próbák, enzimatikus reakciók és a kiválasztott régiók PCR-alapú kinyerésével is, amely messze a legérzékenyebb módszer a szelekcióra [12].

\section{Génkönyvtár-generálás}

A DNS-fragmentumokból az előkészítést követően génkönyvtárat hozunk létre. Ennek a kulcsfontosságú lépésnek a lényege, hogy az eltérő nukleinsavsorrenddel rendelkező fragmentumokra adapterligatio vagy PCR segítségével olyan univerzális adaptereket kapcsolunk, amelyek az ezt követő reakciókban primerekként funkcionálhatnak: ilyenek a klonális amplifikációhoz szükséges primerek, a masszív parallel szekvenálási reakció célszekvenciái, 4-8 bázispárból álló minőség-ellenőrzést szolgáló szekvenciák és 6-8 bázispárból álló vonalkódszekvenciák, amelyek a minta beazonosítását teszik lehetővé [6].

\section{Klonális amplifikáció}

A leképezőrendszerek nagy többsége nem képes egyedülálló fluoreszcens jelek detektálására, ezért a DNSfragmentumokat sokszorosítanunk, más néven amplifikálnunk kell, hogy a fluoreszcenciajelek a DNS mennyiségének növekedése miatt láthatóvá váljanak [8].

Az amplifikáció minden esetben szeparáltan kell, hogy megtörténjen, ezt a DNS-templátok immobilizációjával érhetjük el. Az immobilizáció megvalósítására a két legelterjedtebb módszer az emulziós PCR és a szolidfázisamplifikáció [13].

Emulziós PCR során olyan víz-olaj emulziót hívunk segítségül, amelynek egy vizes cseppjében csupán egy DNS-molekula szeparált amplifikációja mehet végbe. Az amplifikációs lépést követően a keletkezett 100-200 milliónyi klón különféle felületekre vagy mélyedésbe immobilizálható $[14,15,16]$, ahol a további reakció végbemehet.

Szolidfázis-amplifikáció esetén a templátok immobilizációja már az amplifikációs lépés előtt végbemegy, és ez biztosítja a szeparációt is. A módszer lényege, hogy egy lapkára magas denzitású reverz és forward primerek vannak kovalensen felerősítve, amelyek között hídszerú amplifikáció mehet végbe, a DNS folyamatos rögzítése mellett.

Az amplifikációs lépés 100-200 millió templátclustert hoz létre, olyan szabad DNS-végekkel, amelyek lehetővé teszik egy univerzális szekvenáló primer kapcsolódását és ezzel a masszív parallel szekvenálási reakció elindulását. 


\section{Újgenerációs szekvenálás}

A szekvenálási lépés a módszer legfontosabb eleme, célja a vizsgálni kívánt DNS-szakasz nukleotidsorrendjének megállapítása. A klonálisan amplifikált templátok szekvenálásának kivitelezésére a piroszekvenálás, a szemikonduktorszekvenálás, a szintézisalapú szekvenálás és a ligatioalapú szekvenálás áll rendelkezésünkre.

A piroszekvenálás egy biolumineszcencián alapuló metódus, amelynek során az anorganikus pirofoszfát enzimatikus reakciók sorozataképpen látható fényt bocsát ki. A módszer során a reakcióelegyhez limitált mennyiségben dNTP-t adagolnak, amelyek komplementaritás esetén történő beépülésükkor fényt bocsátanak ki (bizonyos clustereknél nem történik beépülés, míg máshol több is történhet), majd a szintézis leáll a további komplementer dNTP-k hiánya miatt. Az emittált fényjelenségek érzékeny kamera segítségével detektálhatóak, sorrendjük és intenzitásuk flowgram formájában ábrázolható, amelyből a DNS szekvenciája megállapítható. A piacon először feltűnt új generációs szekvenálókészülék (Roche/454 sequencing) is ezen az elven múködik $[8,17]$.

A szemikonduktorszekvenálás a piroszekvenáláshoz hasonló elvek alapján múködik, azonban itt a detektáció tárgya fényemisszió helyett a protonemisszió [6] (például Thermo Fischer Scientific Ion Torrent ${ }^{\mathrm{TM}}$ ).

A szintézisen alapuló szekvenálás alapja a szintézishez szükséges nukleotidok beépülése a „négyszínű ciklikus reverzíbilis terminációs metódus" (four-colour cyclic reversible termination - CRT) szerint. Ennek keretein belül a szolid felülethez rögzített, amplifikált DNS-szakaszokhoz a DNS-polimeráz a 3 O' végükön fluorofórokat hordozó (3'O-azidometil) nukleotidokat épít be egyenként, amelyek a beépülésükkor különféle színnel villannak fel, ezáltal jelzik a G, A, C és T sorrendjét. Ezt egy különösen érzékeny optika detektálja. Egy ezt követő lépés során a 3 O' véghez kapcsolódó fluorofór lehasításra kerül, a 3-OH vég pedig egy redukáló ágens, bizonyos tris (2-carboxyethyl)phosphine (TCEP) hatására regenerálódik. Ezek eredményeképpen a fluoreszcens tulajdonság megszűnik és a nukleotid az ezt követő ciklusokban naturális bázisként múködik tovább, a ciklus pedig egy újabb nukleotid beépítésével indul elölrôl [8] (például Illumina ${ }^{\circledR} /$ Solexa Genome Analizer).

A ligatión alapuló szekvenálás módszere jelentősen eltér a többi metódustól, hiszen múködéséhez a DNS-ligáz [18] aktivitását hívja segítségül. A módszer során egyik vagy mindkét végén fluoreszcens jelöléssel ellátott próba hibridizál a komplementer szekvenciához, amelyet a DNS-ligáz hozzáköt a primerhez. A nem kötődött próbák kimoshatóak, míg a kötődött próba a helyén marad, amely fluoreszcencia kibocsátásával jelzi, hogy milyen bázis került a helyére. A reakció ciklikusan megismételhető kimosható próbák vagy új primer hibridizációja segítségével [19] (például Thermo Fisher Scientific SOLiD $\left.{ }^{\mathrm{TM}}\right)$.

\section{Adatanalizis}

Az új generációs eljárásokban közös, hogy a szekvenálási lépést követően hatalmas mennyiségü adat keletkezik. $\mathrm{Az}$ adatanalízis során nagy teljesítményü számítógépek és szoftverek segítségével a génszakaszok azonosításra és elemzésre kerülnek, ezáltal a nagy mennyiségú adatból szerteágazó célokra felhasználható minőségi információ keletkezik.

$\mathrm{Az}$ adatanalízis első lépése a szekvenált génrészletek eredetének felkutatása és ezt követő felsorakoztatása, amelynek során a keletkezett szekvenciákat egy referenciagenomhoz hasonlítjuk, és a bázisok egyezése alapján kromoszomális eredetüket azonosítjuk.

A szekvencia pontos helyének meghatározása után következhet a bioinformatikai analízis, amelynek segítségével fontos információkat tudhatunk meg a vizsgált génrészletről (kifejezettség mértéke és aránya, SNP-variációk stb.). Az analízis elvégzésére számos szoftver áll rendelkezésünkre, ezek száma napjainkig rohamosan nő [20].

\section{Az új generációs szekvenálás használata a noninvazív aneuploidiavizsgálatokban}

\section{Magzati szabad DNS}

Az új generációs szekvenálási eljárások technikai alapjainak áttekintése után fontos tisztáznunk, hogy valójában mire is tudjuk használni ezt a rendkívül ígéretes módszert az aneuploidiák noninvazív vizsgálatában, azaz: tulajdonképpen mi az, amit a magzat és függelékei integritásának megbontása nélkül szekvenálni tudunk?

A kérdésünkre a választ az anyai plazmában fellelhető szabad magzati DNS adja meg.

A szabad DNS olyan 150-200 bázispárból álló [21], a vérplazmában szabadon fellelhető fragmentum, amely bizonyos sejtek apoptózisa következtében szabadul fel [22].

Bár a szabad DNS fennállásának ténye 1947 óta ismert [23], diagnosztikus célból történő használatára csak a kilencvenes évek közepén került sor bizonyos tumorfajtáktól szenvedő betegek plazmájának vizsgálata kapcsán $[24,25]$.

Az aneuploidiák noninvazív diagnosztikájában mérföldkőnek számító felfedezés nem sokkal ezután következett, amikor 1997-ben Lo és mtsai [26] a gyorsan növő magzat és placenta számos tumorszerú tulajdonságából kiindulva először sikeresen izolálták az anyai vérben fellelhető magzati szabad DNS-t Y-kromoszóma-specifikus próba segítségével. Az ezt követô számos vizsgálat során bebizonyosodott, hogy a már potenciálisan hetedik gesztációs héttől detektálható magzati szabad DNS a terhesség első és második trimesztere során az anyai vérben található összes szabad DNS 5-10\%-át teszi ki [27], ezt a mennyiséget gyakran nevezik magzati frakciónak is (fetal fraction-FF). A magzati szabad DNS a placenta 
trophoblast sejtjeinek apoptózisa következtében keletkezik [28] és kerül az anyai véráramba, ahonnan a terhesség megszünte után a máj és a vese közremúködésével [29] gyorsan eliminálódik, átlagos felezési ideje 16,3 GE (genomegység)/perc, ezáltal a szülést követő második órától már nem lehet az anyai vérben szabad magzati DNS-t kimutatni [30].

Előnyös tulajdonságai (korai megjelenés, gyors terhesség utáni elimináció, hozzáférhetőség az anyai vérből) mellett fontos kiemeljük, hogy a magzati szabad DNS az anyaival körülbelül 99\%-os hasonlóságot mutat [31], ezenkívül mennyisége az összes szabad DNS-hez képest csekély, így detektálásához rendkívül érzékeny vizsgálómódszerek szükségesek, amelyek az új generációs eljárások térhódításával napjainkra elérhetővé, és ami szintén lényeges, megfizethetővé váltak (2.ábra).

\section{Az MPS-en alapuló NIPT-vizsgálatok elméleti alapja}

A jelenlegi MPS-en alapuló NIPT-technikák kifejlesztését számos teória segítette, de a lényegi áttörést mégis Fan és mtsai [32] által 2008-ban megfogalmazott elmélet jelentette.

Az elmélet lényege, hogy aneuploidiák esetén a magzati kromoszómaszám megemelkedik (triszómiák, tetra-



2. ábra $\quad$ A nem invazív praenatalis tesztelés jelenleg elterjedt módszerei

szómiák) vagy lecsökken (monoszómiák), amely az anyai és magzati összkromoszomális dózist is kismértékben, de arányosan megemeli vagy lecsökkenti a magzati relatív kromoszóma többletnek/hiánynak köszönhetően.

Az elméletet egy példa segítségével is értelmezhetjük: egy 21-triszómiás, azaz Down-szindrómás magzatot hordó anya vérében a 21-es kromoszómáról származó fragmentumok száma megemelkedik egy referenciamintához/kromoszómához képest, és ebből a kismértékű szelektív összkromoszomális emelkedésból következtethetünk a magzat triszómiás voltára (3. ábra).

MPS segítségével a szabad-DNS-fragmentumok bázissorrendje meghatározható és a fragmentum kro-

ANYAI VÉRMINTA

ANYAI ÉS MAGZATI SZABAD DNS
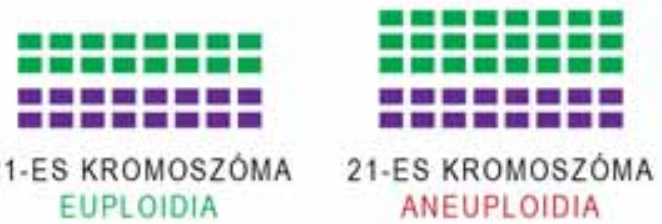

3. ábra

MPS, kromoszómához társítás és számolás a magzati aneuploidia detektálására. Az anyai és magzati szabad DNS izolálása után a teljes szabad-DNS mennyiség szekvenálásra kerül, amely több millió fragmentumot eredményez. A szekvenált mintákat ezután a referenciagenomhoz társítják. A társított szakaszok megszámolását követően az adott kromoszómaploidia státusa tisztázható 
moszómához társítható, ezáltal megszámolhatóak az általunk vizsgálni kívánt kromoszómához tartozó fragmentumok, és azok reprezentáltsági foka a referenciagenomhoz viszonyítva. Mivel a vizsgálat lényege ezekben az esetekben a kérdéses kromoszómákhoz társuló fragmentumok megszámolása és arányba állítása, az MPSalapon múködő rendszereket nevezik kvantitatív vizsgálatoknak is, szemben az SNP-analízisen alapuló módszerekkel, amelyek kvalitatív eljárások.

Összehasonlításképpen: SNP-analízis esetén az anyai buffy coat (anyai SNP-ket megjelenítő frakció) és plazma (anyai és magzati SNP-ket is felvonultató frakció) elválasztásával az anyai és magzati SNP-k egymástól elkülöníthetőek egy multiplex PCR-amplifikációt követő szekvenálás során. Az anyai és magzati SNP-k ezt követően megfelelő kromoszómához társíthatóak, majd a lehetséges rekombináció figyelembevételével a magzati aneuploidia valószínűsége megbecsülhető [33].

A kvantitatív, MPS-en alapuló eljárások feloszthatók a már korábban is említett, minél teljesebb körü, „shotgun” (s-MPS), és előzetes előszelektálással csak az érdekelt kromoszómák szekvenálását kivitelező célzott, „targeted" (t-MPS) kategóriákra.

Az s-MPS-alapon múködő vizsgálatok a lehető legnagyobb számú, egész genomot érintő anyai és magzati fragmentumot szekvenálják, majd az ezt követő alignment (kromoszomális lokalizációhoz társítás) után a vizsgálni kívánt kromoszómák alul- vagy túlreprezentált állapota változatos bioinformatikai módszerekkel (mint például a z-score [34] és az NCV [35]) megválaszolható. Az NCV, azaz normalized chromosome value számítása annyiban különbözik a z-score-számolástól, hogy az emelkedett kromoszomális százalék kimutatására nem egy másik, referenciamintánál mért értéket alkalmazunk, így minimalizálhatóak a különböző minták szekvenálása közötti, vagy akár az adott szekvenálásban megfigyelhető (úgynevezett „interrun” és „intrarun”) különbségek. A kimutatáshoz az ugyanazon mintában mérhető, a vizsgálni kívánt aneuploidiagyanús kromoszómák bázisarányával nagymértékben megegyező, úgynevezett denominátor kromoszómák alkalmazhatóak, ilyen lehet például a 21-es kromoszóma vizsgálatakor a 9-es kromoszóma. Az aneuploidia fennállását a denominátor kromoszóma, mint az azonos mintában megjelenő referencia „intrarun” paraméter előfordulásához képest emelkedett érték jelezheti.

A módszer hatékonysága a nagy mennyiségú adat beolvasásának köszönhetően egyedülálló, ennek köszönhetően alacsony magzati szabad-DNS-frakció, esetleg alacsony mértékü összkromoszomálisdózis-változás esetén is pontos eredménnyel szolgál [9].

A t-MPS-alapon múködő vizsgálatok során a vizsgálni kívánt kromoszómák előzetes szelekción mennek keresztül, a páciensspecifikus kockázat kiszámításához pedig az anyai életkort és a gesztációs időt is figyelembe veszik [36].

\section{A vizsgálat pontos menete}

A vizsgálat pontos menetének ismertetéséhez egy olyan, s-MPS-alapon múködő módszer leírását választottuk, amely 28 millió bevizsgált adatával a piacon jelenleg elérhető legrészletesebb vizsgálatra ad lehetőséget. A módszer során vizsgálható a 21-, 18-, 16-, 13-, 9-triszómia, $\mathrm{X}$-monoszómia, X-triszómia, Klienefelter- (XXY-) és Jacob- (XYY-) szindróma is.

A vizsgálat már a 10. gesztációs héttől elvégezhető, kezdeti lépése az anyai perifériás vérből történő, körülbelül 7-10 ml vér levétele (egy kémcső). A vér levételét követően a mintát a vizsgálatot végző diagnosztikus laboratóriumba szállítják, ahol 24-48 órán belül megtörténik a plazma véralkotóktól történő elválasztása, ezt követően pedig a sejtmentes DNS izolálása. Mivel a megtisztított sejtmentes DNS már eleve körülbelül 170 bázispár hosszúságú fragmentumokból épül fel [37], ezért az MPS részletes leírásában említett fragmentációs lépés kihagyható. A mintegy 170 bázispár hosszúságú DNS-szakaszokat nem kell egészében szekvenálni, mert már az első 36 bázispár szekvenálása elégséges ahhoz, hogy a magzati DNS-töredék pontos kromoszomális származási helye beazonosíthatóvá váljon [38].

A munkafolyamat központi részét a beérkező nagy mennyiségü adat bioinformatikai analízise jelenti, amelyet követően a vizsgált minta három csoportba kerülhet: felismert aneuploidia, nincs felismert aneuploidia, aneuploidia gyanúja.

\section{Az NIPT-vizsgálat elhelyezkedése az aneuploidiadiagnosztika folyamatában}

Az eddig ismertetettekből világosan látható, hogy az új generációs szekvenálási eljárásokon nyugvó noninvazív praenatalis tesztelés, más néven az NIPT egy rendkívül szenzitív és specifikus módszer, amelynek alkalmazása forradalmasította az invazivitást mellőző aneuploidiavizsgálatokat.

A módszerrel kapcsolatban már több társasági ajánlás is született, ilyenek például az ISPD (www.ispdhome. org), NSGC (www.nsgc.org), SMFM (www.smfm.org), RCOG (www.rcog.org.uk), RANZCOG (www.ranzcog. edu.au) által közzétett vélemények.

Az Amerikai Szülész-Nőgyógyászati Társaság Genetikai Szekciójának (American College of Obstetricians and Gynecologists Committee on Genetics) véleménye [39] szerint a magzati szabad DNS vizsgálatán alapuló noninvazív tesztelésben rejlő potenciál igen nagymértékü. Az MPS segítségével egy olyan módszer került kifejlesztésre, amellyel biológiai mintákból DNS-fragmentumok milliói kerülhetnek azonosításra és besorolásra akár pár nap leforgása alatt, így a 13-, 18- és 21 -triszómia már 10 hetes terhességben is akkurátusan kimutatható az anyai plazma levételét követő egy héten belül. Nagyszámú validált tanulmány bizonyítja, hogy bár a teszt nem diagnosztikus értékú, a 13-, 18- és 21 -triszómia esetén a de- 
tekciós ráta kiemelkedően magas, akár 99,9\%-os értéket is elérhet a fals pozitív esetek elenyésző (0,5\%-nál kisebb) megjelenése mellett. Ezen okok miatt a társaság ajánlásában kimondja, hogy a sejtmentes magzati DNS vizsgálata tûnik a legeffektívebb aneuploidiaszürő módszernek magas rizikójú terhesek esetén. Magas rizikójú terhességnek számítanak azok az esetek, ahol az anyai életkor magasabb, mint 35 év, ahol már volt példa a terhességi anamnézisben triszómiára, ahol ultrahangeltérések kapcsán az aneuploidia kockázata fokozott és azok az esetek is, ahol valamelyik szülő genetikai eltérése a triszómiakockázatot fokozza. Magas rizikójú terhesség előfordulása esetén az anyának fel kell ajánlani a tesztelési opciókat, amelynek részeként a sejtmentes magzati DNS-tesztelés mint első szűrési lehetőség is felmerül. A szabad-DNS-alapú tesztelést használhatjuk a jelenleg alkalmazott szűrővizsgálatok mellett (ultrahangvizsgálat, kombinált vagy integrált teszt) második lépcsőben is, az invazív vizsgálat előtt.

A tesztelés felajánlását lehetőség szerint mindig előzze meg konzultáció, hogy a vizsgálatba való beleegyezés egy aktív, informált választás lehessen. A vizsgálat melletti parallel ultrahang-diagnosztika természetesen nem elhanyagolható, a magzat életképessége, a terhesség szingularitásának, egyéb anomáliák megítélésének és a várható gesztációs idő megbecslésének szempontjából. A noninvazív teszten kapott pozitív eredményt mindig szükséges invazív diagnosztikai módszerrel (amniocentesis, chorionboholy-mintavétel) megerősíteni, mert különösen ritka esetben lehetséges mind fals negatív, mind pedig fals pozitív teszt előfordulása. A várandósok figyelmét arra is szükséges felhívni, hogy a teszt csak bizonyos (leggyakoribb) triszómiákat (például 21-, 18-, 16-, 13és 9-triszómia) képes kimutatni, így egy negatív teszt nem jelent feltétlenül egészséges terhességet.

Megfelelő mennyiségű validált adat hiányában az alacsony rizikójú és ikerterhességek esetén a társaság jelenleg nem ajánlja a vizsgálat elvégzését, azonban Bianchi és mtsai [40] 2014 elején egy 1914 várandós bevonásával végzett vizsgálat eredményeképpen közölték, hogy a módszer fals pozitív és pozitív prediktív értékei 18-as és 21-es triszómia esetén a standard szürőmódszereknél tapasztalt értékeknél jóval kedvezőbbek. A munkacsoport által végzett CARE (Comparison of Aneuploidy Risk Evaluation) tanulmány keretein belül a magzati sejtmentes DNS vizsgálata során kapott eredményeket hasonlították össze konvencionális aneuplodiaszürő módszerekkel, ezek között az első trimeszterbeli kombinált, kvartett, szekvenciális és integrált tesztek kaptak helyet. A vizsgálatban részt vevő nók életkorának mediánja 29,6 év volt. A tanulmányból kiderült, hogy a 21 -triszómia esetén tapasztalt fals pozitív ráta sejtmentes DNS-vizsgálata során $0,03 \%$, míg standard módszerek szerint ez az érték 3,6\%-ra tehető. 18-triszómia esetén történő sejtmentes DNS vizsgálatánál ez az érték $0,2 \%$ volt, szemben a standard módszerek mellett tapasztalható $0,6 \%$-kal. A pozitív prediktív érték sejtmen- tes magzati DNS esetén 21-triszómiánál 45\%, míg 18-triszómiánál $40 \%$ volt, szemben a standard módszereknél mérhető 4,2\%-os (21-triszómia) és 8,3\%-os (18-triszómia) értékekkel.

A fentiekben elmondottakból látható, hogy a magzati sejtmentes DNS klinikai használhatósága alacsony és magas kockázatú terhességek esetén is egyaránt kedvező.

\section{Következtetések}

Az új generációs szekvenálási eljárások (NGS) új fejezetet nyitottak a génszekvenálás történetében, hiszen az eltérő kivitelezés ellenére minden felsorolt eljárás esetén gyorsan, pontosan, és ami nem mellékes, egyre csökkenő áron nyerhetünk értékes genetikai információt, amely alig több mint egy évtizeddel ezelőtt még elképzelhetetlen lett volna.

A módszer az aneuploidiák noninvazív vizsgálatát is forradalmasította, hiszen a magzati szabad DNS segítségével a 13-, 18- és 21-triszómia akár már 10 hetes terhességben is rendkívül pontosan kimutatható mindössze egy kémcső anyai perifériás vér levételét követően az új generációs szekvenálási eljárásoknak köszönhetően. Az NIPT térnyerésével egy rendkívül magas (akár >99,9\%) detekciós rátával rendelkező szűrőmódszerrel gazdagodtunk, amelyet a jelenlegi ajánlások szerint magas kockázatú terhességek esetében alkalmazhatunk. A fejlődés azonban korántsem áll meg, hiszen jelenleg is számos tanulmány (például CARE) foglalkozik a vizsgálatok alkalmazásának kiterjesztésével az alacsony kockázatú terhespopulációban is, egyértelmúen kedvező eredménynyel.

Anyagi támogatás: A közlemény megírása, illetve a kapcsolódó kutatómunka anyagi támogatásban nem részesült.

Szerzôi munkamegosztás: Az irodalmi adatok feldolgozását, a kézirat megszövegezését a szerzők közösen végezték. A cikk végleges változatát valamennyi szerző elolvasta és jóváhagyta.

Anyagi érdekeltségek: N. Gy. R.: A Verifi-teszt magyarországi forgalmazásában közremúködik. Egyebekben a szerzőknek nincsenek érdekeltségeik.

\section{Irodalom}

[1] Török, O.: Ultrasound screening of chromosomal abnormalities. In: Tóth, Z., Papp, Z. (eds.): Obstetrics and gynecological ultrasound diagnosis. [Chromosoma-rendellenességek ultrahangszû́rése. In: Tóth, Z., Papp, Z. (szerk.): Szülészet-nőgyógyászati ultrahang-diagnosztika.] White Golden Book Kft., Budapest, 2001. [Hungarian]

[2] Tóth, S., Hegyesi, H.: The organisation of the human genome. In: Tóth, S., Hegyesi, H. (eds.): Introduction to human genetics. [A humán genom szerveződése. In: Tóth, S., Hegyesi, H. 
(szerk.): Bevezetés a humángenetikába.] Semmelweis Kiadó, Budapest, 2007. [Hungarian]

[3] Sanger, F., Nicklen, S., Coulson, A. R.: DNA sequencing with chain-terminating inhibitors. Proc. Natl. Acad. Sci. U.S.A., 1977, 74(12), 5463-5467.

[4] Metzker, M. L., Raghavachari, R., Richards, S., et al.: Termination of DNA synthesis by novel 3'-modified-deoxyribonucleoside 5'-triphosphates. Nucl. Acids Res., 1994, 22(20), 42594267.

[5] Ruiz-Martinez, M. C., Berka, J., Belenkii, A., et al.: DNA sequencing by capillary electrophoresis with replaceable linear polyacrylamide and laser-induced fluorescence detection. Anal. Chem., 1993, 65(20), 2851-2858.

[6] Borsting, C., Morling N.: Next generation sequencing and its applications in forensic genetics. Forensic Sci. Int. Genet., 2015 Feb 14. http://dx.doi.org/10.1016/j.fsigen.2015.02.002. [Epub ahead of print]

[7] Ronaghi, M., Karamohamed, S., Pettersson, B., et al.: Real-time DNA sequencing using detection of pyrophosphate release. Anal. Biochem., 1996, 242(1), 84-89.

[8] Metzker, M. L.: Sequencing technologies - the next generation. Nat. Rev. Genet., 2010, 11(1), 31-46.

[9] Cuckle, H., Benn, P., Pergament, E.: Cell-free DNA screening for fetal aneuploidy as a clinical service. Clin. Biochem., $2015 \mathrm{Feb}$ 27. http://dx.doi.org/10.1016/j.clinbiochem.2015.02.011 [Epub ahead of print]

[10] Voelkerding, K. V., Dames, S. A., Durtschi, J. D.: Next-generation sequencing: from basic research to diagnostics. Clin. Chem., $2009,55(4), 641-658$.

[11] Mardis, E. R.: Next-generation DNA sequencing methods. Annu. Rev. Genomics Hum. Genet., 2008, 9, 387-402.

[12] Mamanova, L., Coffey, A. J., Scott, C. E., et al.: Target-enrichment strategies for next-generation sequencing. Nat. Methods, $2010,7(2), 111-118$

[13] Dressman, D., Yan, H., Traverso, G., et al.: Transforming single DNA molecules into fluorescent magnetic particles for detection and enumeration of genetic variations. Proc. Natl. Acad. Sci. U.S.A., 2003, $100(15), 8817-8822$.

[14] Shendure, J., Porreca, G. J., Reppas, N. B., et al.: Accurate multiplex polony sequencing of an evolved bacterial genome. Science, 2005, 309(5741), 1728-1732.

[15] Kim, J. B., Porreca, G. J., Song, L., et al.: Polony multiplex analysis of gene expression (PMAGE) in mouse hypertrophic cardiomyopathy. Science, 2007, 316(5830), 1481-1484.

[16] Leamon, J. H., Lee, W. L., Tartaro, K. R., et al.: A massively parallel PicoTiterPlate ${ }^{\mathrm{TM}}$ based platform for discrete picoliter-scale polymerase chain reactions. Electrophoresis, 2003, 24(21), 3769-3777.

[17] Margulies, M., Egholm, M., Altman, W. E., et al.: Genome sequencing in microfabricated high-density picolitre reactors. Nature, 2005, 437(7057), 376-380

[18] Tomkinson, A. E., Vijayakumar, S., Pascal, J. M., et al.: DNA ligases: structure, reaction mechanism, and function. Chem. Rev., 2006, 106(2), 687-699.

[19] Landegren, U., Kaiser, R., Sanders, J., et al.: A ligase-mediated gene detection technique. Science, 1988, 241(4869), 10771080.

[20] Mibály, Zs., Györffy, B.: Next generation sequencing technologies (NGST) development and applications. [Következő generációs szekvenálási technológiák kifejlődése és alkalmazásai.] Orv. Hetil., 2011, 152(2), 55-62. [Hungarian]

[21] Chan, K. C., Zhang, J., Hui, A. B., et al.: Size distributions of maternal and fetal DNA in maternal plasma. Clin. Chem., 2004, $50(1), 88-92$.

[22] Giacona, M. B., Ruben, G. C., Iczkowski, K. A., et al.: Cell-free DNA in human blood plasma: length measurements in patients with pancreatic cancer and healthy controls. Pancreas, 1998, $17(1), 89-97$
[23] Mandel, P., Metais, P.: Les acides nucleiques du plasma sanguin chez l'homme. C. R. Acad. Sci. Paris, 1948, 142(3-4), 241-243. [French]

[24] Chen, X. Q., Stroun, M., Magnenat, J. L., et al:: Microsatellite alterations in plasma DNA of small cell lung cancer patients. Nat. Med., 1996, 2(9), 1033-1035.

[25] Nawroz, H., Koch, W., Anker, P., et al.: Microsatellite alterations in serum DNA of head and neck cancer patients. Nat. Med., 1996, 2(9), 1035-1037.

[26] Lo, Y. M., Corbetta, N., Chamberlain, P. F., et al.: Presence of fetal DNA in maternal plasma and serum. Lancet, 1997, 350 (9076), 485-487.

[27] Lun, F. M., Chiu, R. W., Chan, K. C., et al.: Microfluidics digital PCR reveals a higher than expected fraction of fetal DNA in maternal plasma. Clin. Chem., 2008, 54(10), 1664-1672.

[28] Alberry, M., Maddocks, D., Jones, M., et al.: Free fetal DNA in maternal plasma in anembryonic pregnancies: confirmation that the origin is the trophoblast. Prenat. Diagn., 2007, 27(5), 415418.

[29] Tsumita, T., Iwanaga, M.: Fate of injected deoxyribonucleic acid in mice. Nature, 1963, 198, 1088-1089.

[30] Lo, Y. M., Zhang, J., Leung, T. N., et al.: Rapid clearance of fetal DNA from maternal plasma. Am. J. Hum. Genet., 1999, 64(1), 218-224.

[31] Swanson, A., Sehnert, A. J., Bhatt, S.: Non-invasive prenatal testing: technologies, clinical assays and implementation strategies for women's healthcare practitioners. Curr. Genet. Med. Rep., 2013, I(2), 113-121.

[32] Fan, H. C., Blumenfeld, צ. J., Chitkara, U., et al.: Noninvasive diagnosis of fetal aneuploidy by shotgun sequencing DNA from maternal blood. Proc. Natl. Acad. Sci. U.S.A., 2008, 105(42), 16266-16271.

[33] Zimmermann, B., Hill, M., Gemelos, G., et al.: Noninvasive prenatal aneuploidy testing of chromosomes 13, 18, 21, X, and Y, using targeted sequencing of polymorphic loci. Prenat. Diagn., 2012, 32(13), 1233-1241.

[34] Chiu, R. W., Chan, K. C., Gao, Y., et al.: Noninvasive prenatal diagnosis of fetal chromosomal aneuploidy by massively parallel genomic sequencing of DNA in maternal plasma. Proc. Natl. Acad. Sci. U.S.A., 2008, 105(51), 20458-20463.

[35] Sehnert, A. J., Rhees, B., Comstock, D., et al.: Optimal detection of fetal chromosomal abnormalities by massively parallel DNA sequencing of cell-free fetal DNA from maternal blood. Clin. Chem., 2011, 57(7), 1042-1049.

[36] Sparks, A. B., Wang, E. T., Struble, C. A., et al.: Selective analysis of cell-free DNA in maternal blood for evaluation of fetal trisomy. Prenat. Diagn., 2012, 32(1), 3-9.

[37] Fan, H. C., Blumenfeld, Y. J., Chitkara, U., et al.: Analysis of the size distributions of fetal and maternal cell-free DNA by pairedend sequencing. Clin. Chem., 2010, 56(8), 1279-1286.

[38] Bianchi, D. W., Platt, L. D., Goldberg, J. D., et al.: Genome-wide fetal aneuploidy detection by maternal plasma DNA sequencing. Obstet. Gynecol., 2012, 119(5), 890-901. [Erratum, Obstet. Gynecol., 2012, 120(4), 957.]

[39] American College of Obstetricians and Gynecologists Committee on Genetics: Committee Opinion No. 545: Noninvasive prenatal testing for fetal aneuploidy. Obstet. Gynecol., 2012, 120(6), 1532-1534.

[40] Bianchi, D. W., Parker, R. L., Wentworth, J., et al.: DNA sequencing versus standard prenatal aneuploidy screening. N. Engl. J. Med., 2014, 370(9), 799-808.

(Babay Lilla Éva orvostanhallgató, Budapest, Baross u. 27., 1088 e-mail: lilla.babay@gmail.com) 